\title{
Sequence Characterization of Mitochondrial 12S rRNA Gene in Mouse Deer (Moschiola indica) for PCR-RFLP Based Species Identification
}

\author{
Chandra Mohan Siddappa, ${ }^{1}$ Mohini Saini, ${ }^{1}$ Asit Das, ${ }^{1}$ Ramesh Doreswamy, ${ }^{1,2}$ \\ Anil K. Sharma, ${ }^{1}$ and Praveen K. Gupta ${ }^{3}$ \\ ${ }^{1}$ Centre for Wildlife, Indian Veterinary Research Institute, Izzatnagar, Uttar Pradesh 243 122, India \\ ${ }^{2}$ Department of Veterinary Physiology \& Biochemistry, Veterinary College, KVAFSU, Hassan, Karnataka 573201, India \\ ${ }^{3}$ Division of Animal Biotechnology, Indian Veterinary Research Institute, Izzatnagar, Uttar Pradesh 243 122, India \\ Correspondence should be addressed to Mohini Saini; mohini@ivri.res.in
}

Received 30 September 2013; Revised 20 November 2013; Accepted 20 November 2013

Academic Editor: Malayannan B. Subramaniam

Copyright (C) 2013 Chandra Mohan Siddappa et al. This is an open access article distributed under the Creative Commons Attribution License, which permits unrestricted use, distribution, and reproduction in any medium, provided the original work is properly cited.

\begin{abstract}
Mitochondrial $12 \mathrm{~S}$ rRNA has proven to be a useful molecular marker for better conservation and management of the endangered species. Polymerase chain reaction-restriction fragment length polymorphism (PCR-RFLP) of the mitochondrial 12S rRNA gene has proven to be a reliable and efficient tool for the identification of different Indian deer species of family cervidae. In the present study, mitochondrial $12 \mathrm{~S}$ rRNA gene sequence of mouse deer (Moschiola indica) belonging to the family Tragulidae was characterized and analysed in silico for its use in species identification. Genomic DNA was isolated from the hair follicles and mitochondrial $12 \mathrm{~S}$ rRNA gene was amplified using universal primers. PCR product was cloned and sequenced for the first time. The sequence of mouse deer showed 90.04, 90.08, 90.04, 91.2, 90.04, and 90.08\% identities with sika deer, sambar, hog deer, musk deer, chital, and barking deer, respectively. Restriction mapping in Lasergene (DNAstar Inc., Madison, WI, USA) revealed that mouse deer mitochondrial $12 \mathrm{~S}$ rRNA gene sequence can be differentiated from the other deer species in PCR-RFLP using RsaI, DdeI, BsrI, and BstSFI. With the help of predicted pattern, mouse deer can be identified using genomic DNA from a variety of biomaterials, thereby providing molecular aid in wildlife forensics and conservation of the species.
\end{abstract}

\section{Introduction}

Use of different molecular markers has evolved as a powerful tool in species identification. Earlier, techniques like liquid chromatography [1], immunoassay [2], electrophoresis [3], and so forth were used in species identification. In recent years, use of DNA has been popularized due to its specificity and stability. Among types of DNA [4,5], mitochondrial DNA has been used extensively due to high copy number of mitochondria in cell. Mitochondria follow clonal inheritance [6] as only mother to contributes to mitochondria; its genome does not undergo recombination; thus, genetic material will be passed onto the next generation unchanged. Reports also suggest that mitochondrial genome is accumulating high percentage of neutral mutations which is helpful in species identification.

Different mitochondrial genes have been used in species differentiation. PCR amplification of cytochrome $b$ gene has been used in differentiation of meats from buffalo, emu, and crocodile [7]. Cytochrome $b$ has also been used in differentiation of processed products like canned tuna, vegetable oil, and tomato sauce [8]. Other mitochondrial genes like $12 \mathrm{~S}$ and $16 \mathrm{~S}$ rRNA are extensively used in mammalian species identification. Numerous molecular techniques have been developed based on the use of mitochondrial 12S rRNA gene identification like RAPD fingerprinting [9], DNA hybridization [10], restriction fragment length polymorphism [11, 12], real time PCR [13], and so forth. Mitochondrial 12S rRNA based 
PCR- RFLP has been used to differentiate peacock from other poultry species [14] and nilgai from cattle and buffalo [15] as well as differentiation of different deer species belonging to the family Cervidae [16].

Mouse deer also known as chevrotain are small ungulates that belong to the family Tragulidae found in forests of South and Southeast Asia. Indian spotted mouse deer Moschiola indica has been recently segregated as a species separately from Moschiola meminna [17]. Indian mouse deer, the smallest ungulate in world, lives in solitary or pairs, feeds on plant material, and weighs 1.5 to $18 \mathrm{lbs}$ [18]. Like other ruminants, it has four chambered stomach but third chamber is poorly developed. It is known to evolve from Oligocene 34 million years ago and remained as a primitive ruminant [19]. Mouse deer has been considered as Schedule I animal in Wildlife Protection Act 1972 as its population is declining due to poaching. The poaching is for its skin and meat largely for the pot and often meat is sold in local market (IUCN red list threatened species 2013, http://www.iucnredlist.org/ details/136585/0). In the present study, partial sequence of mitochondrial $12 \mathrm{~S}$ rRNA gene in Indian mouse deer has been characterized for the first time as a tool for species differentiation using PCR-RFLP.

\section{Materials and Method}

2.1. Sample. Hairs were collected from Indian spotted mouse deer under captivity at Pilikula Zoo, Mangalore, Karnataka, India, and brought to the laboratory under cold conditions.

2.2. Isolation of Genomic DNA. Genomic DNA was isolated from hair follicles using QIAmp tissue extraction kit as per the manufacturer's instructions. The isolated DNA was checked for integrity in $0.8 \%$ agarose gel electrophoresis in Tris-acetate EDTA buffer ( $40 \mathrm{mM}$ Tris-acetate, 2 mM EDTA, pH 8.0) [20].

2.3. Amplification of Mitochondrial $12 S$ rRNA Gene. Mitochondrial 12S rRNA gene was amplified using reported [21] universal primers of $12 \mathrm{~S}$ rRNA, forward primer: $5^{\prime} \mathrm{CAA} A C T$ GGG ATT AGA TAC CCC ACT AT $3^{\prime}$ and reverse primer: $5^{\prime}$ GAG GGT GAC GGG CGG TGT GT $3^{\prime}$. Reaction was set up in $50 \mu \mathrm{L}$ volume consisting of $10 \mathrm{X}$ buffer $5.0 \mu \mathrm{L}(10 \mathrm{mM}$ Tris- $\mathrm{HCl}, 50 \mathrm{mM} \mathrm{KCl}$, and $1.5 \mathrm{mM} \mathrm{MgCl}_{2}$ ), $0.2 \mathrm{mM}$ dNTPs, $20 \mathrm{pmol}$ of each primer, $200 \mathrm{ng}$ template, and $1.5 \mathrm{U}$ proof reading enzyme (Fermentas). Amplification was carried out in a thermal cycler comprising initial denaturation at $94^{\circ} \mathrm{C}$ for $5 \mathrm{~min}$, followed by 35 cycles of denaturation $94^{\circ} \mathrm{C}$ for $45 \mathrm{sec}$, annealing at $59^{\circ} \mathrm{C}$ for $45 \mathrm{sec}$, and extension at $72^{\circ} \mathrm{C}$ for $1.0 \mathrm{~min}$. Final extension was carried out at $72^{\circ} \mathrm{C}$ for $5 \mathrm{~min}$. The amplicon was separated in $1 \%$ agarose gel electrophoresis and the gel spliced product was purified using QIAquick gel extraction kit as per manufacturer's instructions (QIAGEN).

2.4. Cloning and Characterization. The purified product was ligated into pJET 2.1 blunt end cloning vector (Invitrogen) using T4 DNA ligase. The ligated product was transformed in to $E$. coli $\mathrm{DH} 5 \alpha$ competent cell as per transformation protocol by Chung et al. (1989) and plated onto LB agar with

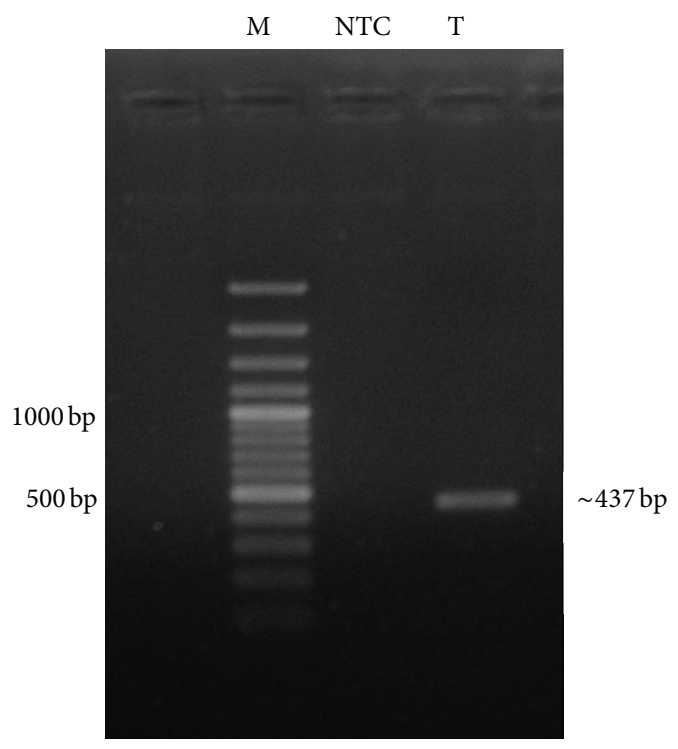

FIGURE 1: Analysis of the PCR amplicon in 1\% agarose gel electrophoresis containing $0.5 \mu \mathrm{g} / \mathrm{mL}$ ethidium bromide. Lane M: $100 \mathrm{bp}$ plus DNA ladder, Lane NTC: no template control, and Lane T: PCR amplicon.

ampicillin $(50 \mu \mathrm{g} / \mathrm{mL})$ as marker. The plate was incubated at $37^{\circ} \mathrm{C}$ overnight. The obtained colonies were picked into $5 \mathrm{~mL} \mathrm{LB}$ broth with ampicillin and grown at $37^{\circ} \mathrm{C}$ overnight under constant shaking at $200 \mathrm{rpm}$. Plasmids were isolated from overnight grown culture according to standard alkaline miniprep protocol [20].

Recombinant plasmids were screened by PCR as described earlier with T7 universal primer. Plasmids were also subjected to restriction digestion with Not 1 enzyme. Reaction mixture consisted of $10 \mathrm{X}$ buffer $\mathrm{O} 2 \mu \mathrm{L}$, plasmid $(1 \mu \mathrm{g} / \mathrm{mL}) 5 \mu \mathrm{L}$, and Not $12 \mu \mathrm{L}$ and final volume was made to be $20 \mu \mathrm{L}$. Mixture was incubated at $37^{\circ} \mathrm{C}$ for $16 \mathrm{~h}$ and digestion pattern was checked by running $1 \%$ agarose gel electrophoresis containing $0.5 \mu \mathrm{g} / \mathrm{mL}$ ethidium bromide. The recombinant plasmid was sequenced at Xcelris Labs Ltd., Anand, Gujarat.

2.5. Sequence Analysis. Mitochondrial 12S rRNA gene sequence of Indian mouse deer was analysed with sequences of other deer species like barking deer (AF294731), sambar (M35875), sika deer (AY184433), chital (DQ017832), hog deer (AY775785), and Himalayan musk deer (AY847268) available at NCBI genbank using DNAstar software. Sequence was also used to construct RFLP plot with common restriction enzymes used in other deer species for species identification.

\section{Results}

PCR amplification has provided $12 \mathrm{~S}$ mitochondrial rRNA gene of nearly $437 \mathrm{bp}$ (Figure 1) long nucleotide sequence which was visualized by gel electrophoresis. The recombinant plasmid encoding the amplicon was sequenced which also provided $437 \mathrm{bp}$ sequence. The obtained sequence was blast 
TABLE 1: RFLP between different deer species.

\begin{tabular}{|c|c|c|c|c|c|}
\hline Deer species & Amplicon (bp) & $R s a \mathrm{I}(\mathrm{bp})$ & DdeI (bp) & $B s r I(b p)$ & BstSFI (bp) \\
\hline Indian mouse deer & 437 & 360 & 348 & $179+249$ & $146+291$ \\
\hline Barking deer & 440 & $175+190$ & 380 & 431 & 440 \\
\hline Chital & 440 & $152+212$ & 379 & $179+252$ & 440 \\
\hline Himalayan musk deer & 440 & 360 & 346 & 431 & 440 \\
\hline Hog deer & 440 & $152+212$ & 379 & 431 & 440 \\
\hline Sambar & 440 & $152+212$ & 316 & 431 & 440 \\
\hline Sika deer & 440 & $152+212$ & 316 & 431 & $186+254$ \\
\hline
\end{tabular}

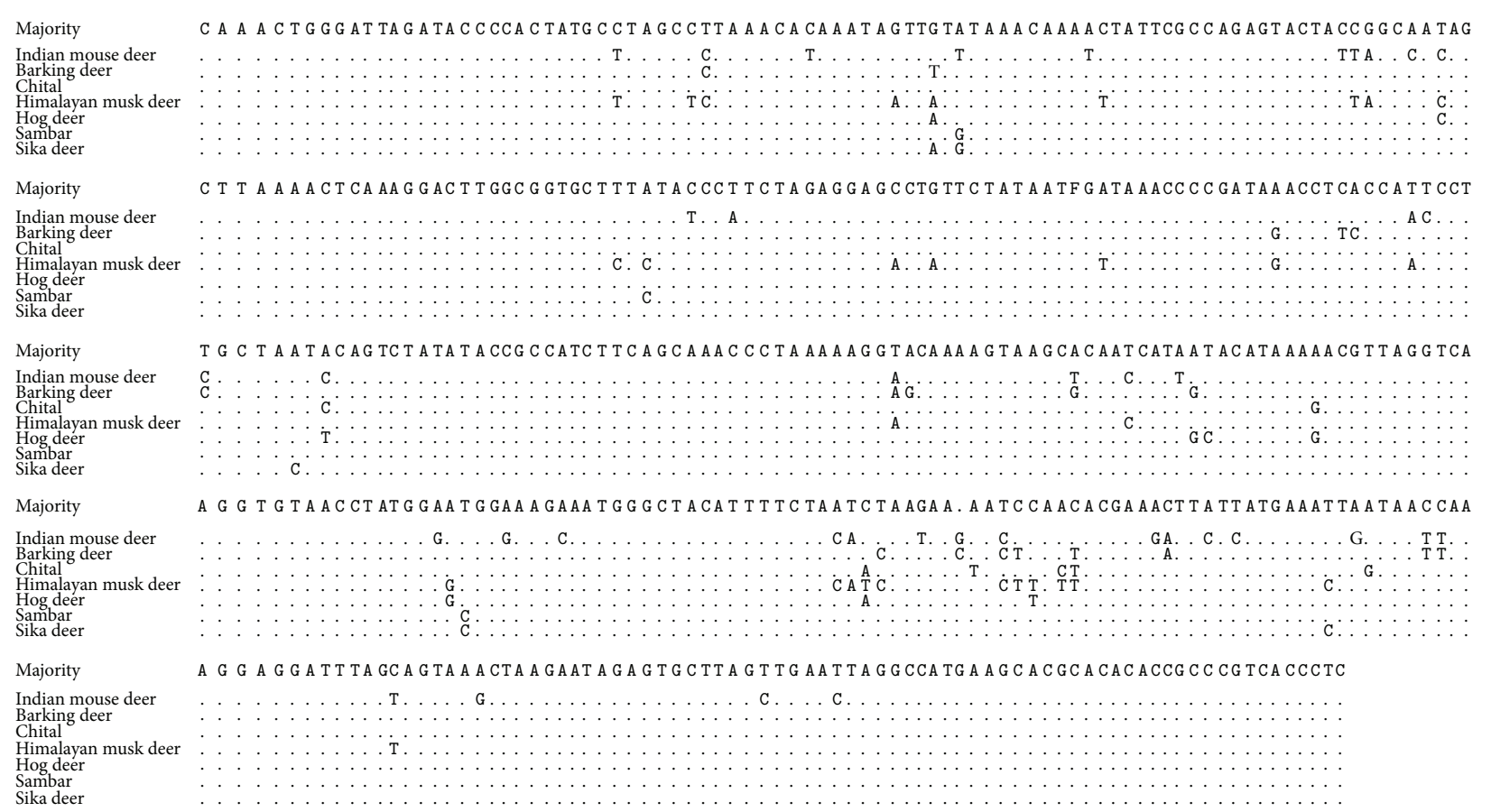

FIGURE 2: Alignment report of mouse deer 12S mitochondrial rRNA gene sequence with other deer species sequences in Lasergene (DNAstar).

analysed at NCBI genbank. The sequence submitted to NCBI genbank has been assigned Accession JX570670.1.

Further sequence was analysed in silico with other available $12 \mathrm{~S}$ mitochondrial rRNA sequences deer species with the help of Lasergene (DNAstar Inc., Madison, WI, USA).

Alignment report at nucleotide level showed 90.04, 90.08, 90.04, 91.2, 90.04, and 90.08 percent identity with sika deer, sambar, hog deer, musk deer, chital, and barking deer, respectively. This homology shows close relationship with other deer species (Figure 2). Phylogenetic relationship shows early evolution of mouse deer as separate cluster different from other deer species (Figure 3).

The nucleotide sequence was further analysed with the help of Lasergene (DNAstar Inc., Madison, WI, USA) for restriction mapping which aids in species identification. Fragments predicted in software which cannot be separated in gel electrophoresis have been ignored. Digestion with RsaI, DdeI, BsrI, and BstSFI is expected to reveal fragments of $360 \mathrm{bp}, 348 \mathrm{bp}, 179+249 \mathrm{bp}$, and $146+291 \mathrm{bp}$, respectively (Figure 4 and Table 1).

\section{Discussion}

Many types of molecular markers are used in species identification; among them mitochondrial $12 \mathrm{~S}$ and $16 \mathrm{~S}$ rRNA gene have been used extensively due to clonal inheritance of mitochondria without recombination and sequence change. Over a period mitochondrial genome is also accumulating neutral mutations [6], leading to change in restriction enzyme recognition patterns which help in species identification. In the present study mitochondrial $12 \mathrm{~S}$ rRNA gene was used as molecular marker for differentiation of Indian mouse deer from other deer species. Amplicon comprising 437 bp was amplified using universal primers which can amplify corresponding region of various organisms including birds and insects [21]. Sequencing and blast analysis of the sequence at NCBI confirmed its identity with other deer species.

Sequence analysis with mitochondrial $12 \mathrm{~S}$ rRNA gene of other deer species has shown more than $90 \%$ similarity which confirms the close relationship with other deer species. Mouse deer belongs to the family Tragulidae, known to evolve 


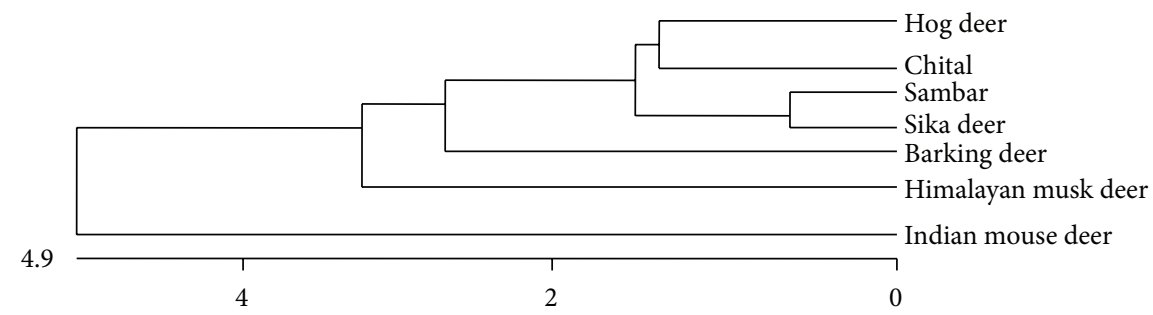

FIGURE 3: Phylogenetic tree constructed using DNAstar in silico software.

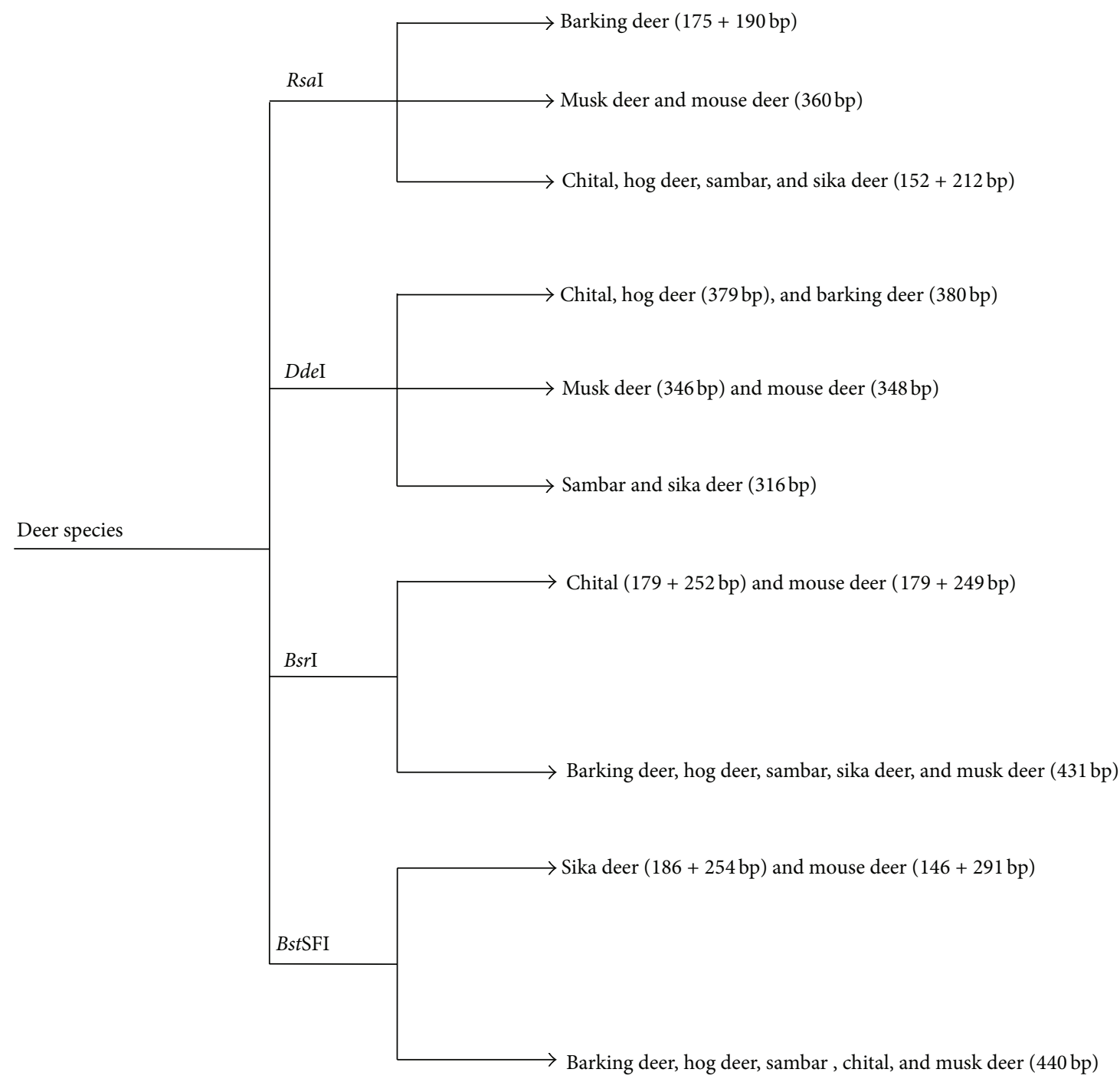

FIGURE 4: : Restriction fragment length polymorphism (RFLP) of mouse deer and its comparison with other deer species of family Cervidae for species differentiation.

very early from Oligocene as primitive ruminant [22]. It is also different from other deer as the third chamber of rumen is poorly developed [23]. From phylogenetic analysis it is evident that it evolved very early as a separate cluster from other deer species family Cervidae (Figure 3). Though nucleotide sequence showed more than 90\% homology, the difference in remaining sequence can be used in species differentiation with restriction fragment length polymorphism (RFLP). Restriction digestion with RsaI has given fragment of $360 \mathrm{bp}$ which is similar to musk deer but barking deer $(175+190 \mathrm{bp})$ and chital, hog deer, sambar, and sika deer $(152+212$ bp) (Gupta et al., 2008) yield different pattern. Thus, 
RsaI enzyme can be used to differentiate Indian mouse deer from other deer except musk deer (Figure 4 and Table 1).

Digestion with DdeI also yields the same pattern as that of musk deer. The mitochondrial 12S rRNA gene of mouse deer is having two recognition sites for both BsrI and BstSFI which is likely to produce two fragments $(179+249 \mathrm{bp}$ and $146+291$ bp resp.,) but musk deer sequence yields only one fragment as it has one recognition site. This can be used to differentiate mouse deer from musk deer (Figure 4 and Table 1). Poaching for the purpose of meat is main threat to Indian mouse deer. With the help of predicted pattern in PCR-RFLP, mouse deer can be identified using genomic DNA isolated from skin or meat samples thereby providing legal molecular aid in wildlife forensics.

\section{Conclusion}

In the present study nearly 437 bp mitochondrial $12 \mathrm{~S}$ rRNA gene of Indian mouse deer was amplified. The amplicon was sequenced and analysed in silico with other available sequences of deer species. Sequence analysis and restriction mapping in Lasergene (DNAstar Inc., Madison, WI, USA) confirmed the usefulness of $12 \mathrm{~S}$ rRNA gene as molecular marker for differentiation of mouse deer from other species. Thus, it can be concluded that PCR-RFLP based analysis of mitochondrial $12 \mathrm{~S}$ rRNA gene can be used as a tool for identification of mouse deer. This will be useful in providing molecular aid in wildlife forensics and conservation of the mouse deer.

\section{Acknowledgments}

The authors are grateful to the Director, the Joint Director (academics), and the Joint Director (research) of the Indian Veterinary Research Institute, Izzatnagar, for providing necessary facilities to conduct the present study. Financial support from ICAR to the first author as ICAR-JRF is also acknowledged.

\section{References}

[1] P. Dratch, J. Shafer, R. Hoesch, and E. Espinoza, "Comparison of electrophoretic and chromatographic methods for analysis of deer haemoglobins," The International Society of Animal Genetics, vol. 27, pp. 17-42, 1996.

[2] D. H. Ubelaker, J. M. Lowenstein, and D. G. Hood, "Use of solidphase double-antibody radioimmunoassay to identify species from small skeletal fragments," Journal of Forensic Sciences, vol. 49, no. 5, pp. 924-929, 2004.

[3] J. Abraham, "Detection of species specific origin of meats of wild animals by isoelectric focusing in," in Proceedings of the 1st Annual Convention of Association of Indian Zoo and Wildlife Veterinarians and Workshop an Basics of Captive Wild Animal Management, pp. 139-144, Indian Veterinary Research Institute, Izatnagar, India, 26-28 April, 2001.

[4] V. J. Birstein, P. Doukakis, B. Sorkin, and R. Desalle, "Population aggregation analysis of caviar producing species of sturgeons and implications for diagnosis of black caviar," Conservation Biology, vol. 12, no. 4, pp. 766-775, 1998.
[5] G. Amato, M. G. Egan, and A. Rabinowitz, "A new species of muntjac, Muntiacus putaoensis (Artiodactyla: Cervidae) from northern Myanmar," Animal Conservation, vol. 2, no. 1, pp. 1-7, 1999.

[6] N. Galtier, B. Nabholz, S. Glémin, and G. D. D. Hurst, "Mitochondrial DNA as a marker of molecular diversity: a reappraisal," Molecular Ecology, vol. 18, no. 22, pp. 4541-4550, 2009.

[7] A. R. R. Forrest and P. R. Carnegie, "Identification of gourmet using FINS (forensically informative nucleotide sequencing)," Biotechniques, vol. 17, no. 1, pp. 24-26, 1994.

[8] M. Unseld, B. Beyermann, P. Brandt, and R. Hiesel, "Identification of the species origin of highly processed meat products by mitochondrial DNA sequences," PCR Methods and Applications, vol. 4, no. 4, pp. 241-243, 1995.

[9] J. C.-I. Lee and J.-G. Chang, "Random amplified polymorphic DNA polymerase chain reaction (RAPD PCR) fingerprints in forensic species identification," Forensic Science International, vol. 67, no. 2, pp. 103-107, 1994.

[10] R. S. Blackett and P. Keim, "Big game species identification by deoxyribonucleic acid (DNA) probes," Journal of Forensic Sciences, vol. 37, no. 2, pp. 590-596, 1992.

[11] R. Meyer, C. Höfelein, J. Lüthy, and U. Candrian, “Polymerase chain reaction-restriction fragment length polymorphism analysis: a simple method for species identification in food," Journal of AOAC International, vol. 78, no. 6, pp. 1542-1551, 1995.

[12] B. W. Murray, R. A. McClymont, and C. Strobeck, "Forensic identification of ungulate species using restriction digests of PCR-amplified mitochondrial DNA," Journal of Forensic Sciences, vol. 40, no. 6, pp. 943-951, 1995.

[13] M. López-Andreo, L. Lugo, A. Garrido-Pertierra, M. I. Prieto, and A. Puyet, "Identification and quantitation of species in complex DNA mixtures by real-time polymerase chain reaction," Analytical Biochemistry, vol. 339, no. 1, pp. 73-82, 2005.

[14] M. Saini, D. K. Das, A. Dhara, D. Swarup, M. P. Yadav, and P. K. Gupta, "Characterisation of peacock (Pavo cristatus) mitochondrial $12 \mathrm{~S}$ rRNA sequence and its use in differentiation from closely related poultry species," British Poultry Science, vol. 48, no. 2, pp. 162-166, 2007.

[15] M. Saini, D. K. Das, A. Dhara, D. Swarup, A. K. Sharma, and P. K. Gupta, "A PCR-RFLP tool for differentiating cattle, buffalo and nilgai," Indian Journal of Animal Sciences, vol. 78, no. 6, pp. 652-654, 2008.

[16] A. R. Gupta, R. C. Patra, D. K. Das, P. K. Gupta, D. Swarup, and M. Saini, "Sequence characterization and polymerase chain reaction-restriction fragment length polymorphism of the mitochondrial DNA $12 \mathrm{~S}$ rRNA gene provides a method for species identification of Indian deer," Mitochondrial DNA, vol. 19, no. 4, pp. 394-400, 2008.

[17] C. Groves and E. Meijaard, "Intraspecific variation in Moschiola, the Indian Chevrotain," The Raffles Bulletin of Zoology, supplement 12, pp. 413-421, 2005.

[18] R. M. Nowak, Ed., Walker's Mammals of the World, Johns Hopkins University Press, Baltimore, Md, USA, 6th edition, 1999.

[19] J. Kingdon, The Kingdon Field Guide to African Mammals, Academic Press, New York, NY, USA, 1997.

[20] J. Sambrook and D. W. Russell, Molecular Cloning: A Laboratory Manual, Cold Spring Harbor Laboratory Press, Cold Spring Harbor, NY, USA, 2001.

[21] T. D. Kocher, W. K. Thomas, A. Meyer et al., "Dynamics of mitochondrial DNA evolution in animals: amplification and 
sequencing with conserved primers," Proceedings of the National Academy of Sciences of the United States of America, vol. 86, no. 16, pp. 6196-6200, 1989.

[22] G. Métais, Y. Chaimanee, J.-J. Jaeger, and S. Ducrocq, "New remains of primitive ruminants from Thailand: evidence of the early evolution of the Ruminantia in Asia," Zoologica Scripta, vol. 30, no. 4, pp. 231-248, 2001.

[23] U. Farooq, M. A. Khan, M. Akhtar, and A. M. Khan, "Lower dentition of Dorcatherium majus (Tragulidae, Mammalia) in the lower and middle Siwaliks (Miocene) of Pakistan," Turkish Journal of Zoology, vol. 32, no. 1, pp. 91-98, 2008. 

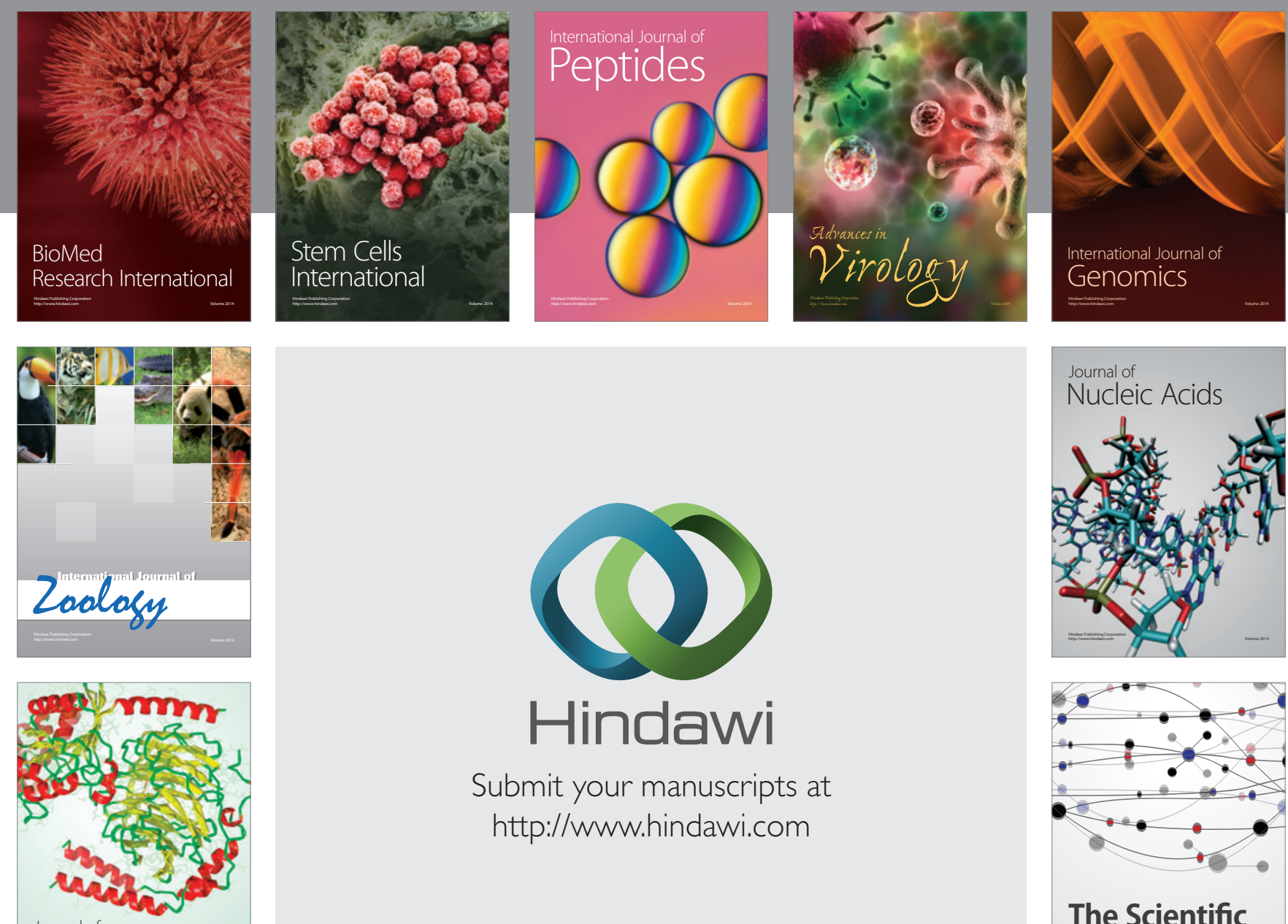

Submit your manuscripts at

http://www.hindawi.com

Journal of
Signal Transduction
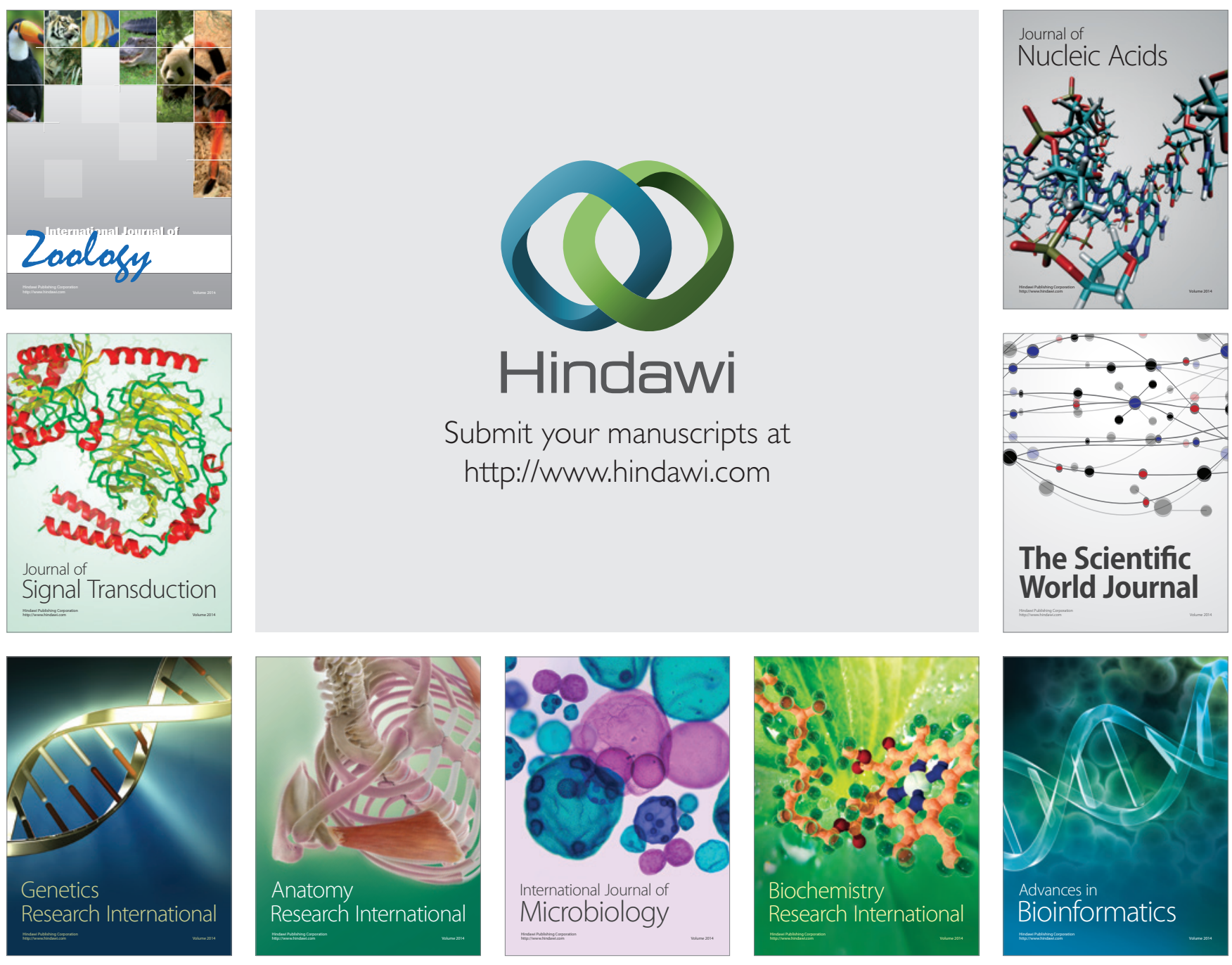

The Scientific World Journal
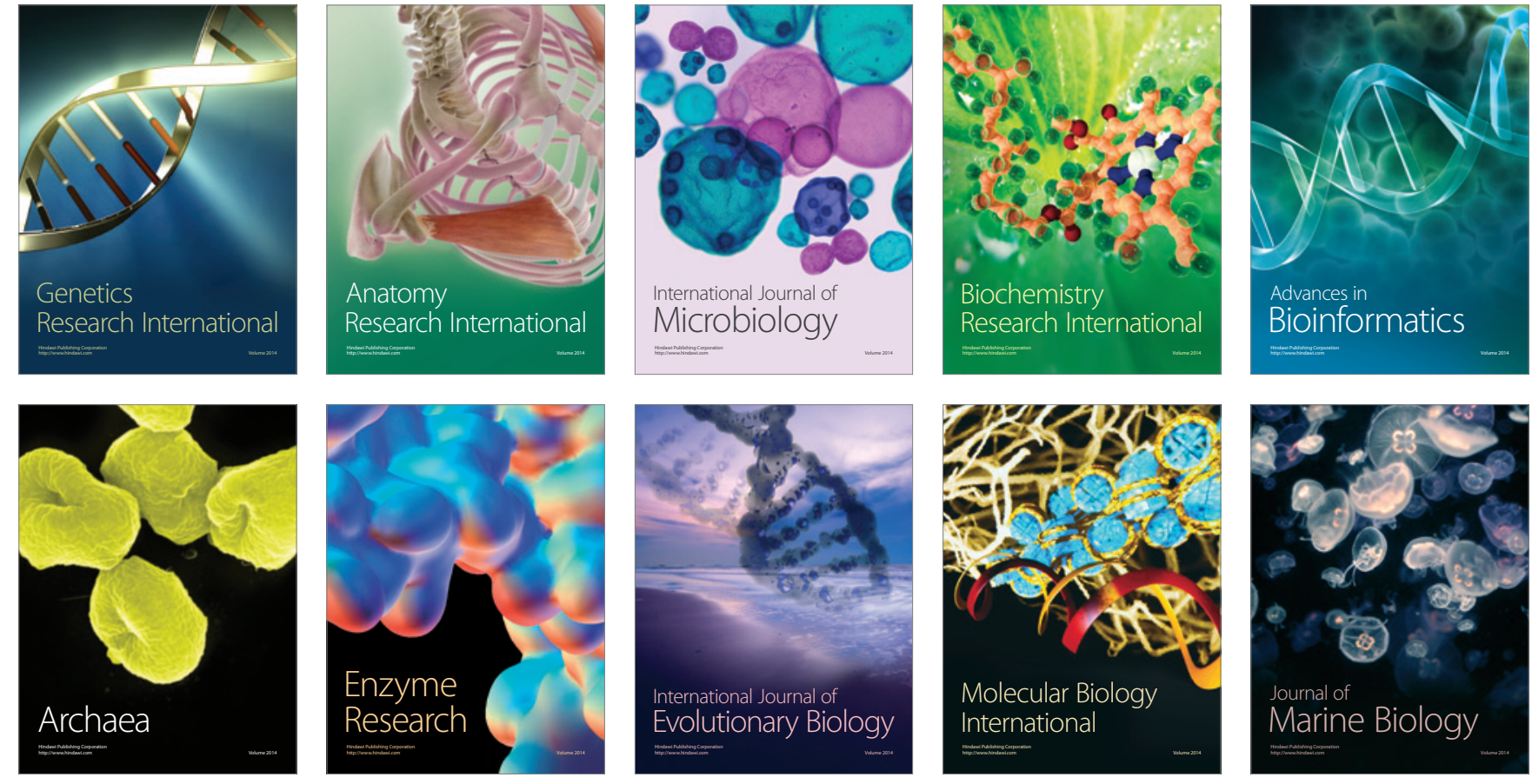